\title{
PERANAN ROH KUDUS \\ DALAM PERTUMBUHAN IMAN ORANG PERCAYA \\ DAN PENERAPANNYA DALAM KELAS PENDIDIKAN \\ AGAMA KRISTEN
}

Oleh: Ramses Simanjuntak ${ }^{1}$

\section{Abstract}

Today, most of believers are still relying on their strenght and taught to do thier daily activities. Sometimes, they are forget that they still need helps and God's intervention. Before Jesus ascended into heaven, He promised that he would send the Holy Spirit to His disciples (Luke 24: 49). Not just that promise, He also promised that He would be with them until the end of the age (Mat. 28: 20). These passages show that God takes the roles in believers daily life.

Key words : Holy spirit, christian education, spiritual growth

\section{Pendahuluan}

Dalam penulisan jurnal yang berjudul: "Peranan Roh Kudus Dalam Pertumbuhan Iman Orang Percaya," maka, penulis mencoba untuk mengetengahkan fakta-fakta yang benar dan aktual tentang Roh Kudus dan tentang kehidupan orang percaya yang gunanya sebagai karya ilmiah untuk memberikan kontribusi bagi banyak orang.

Agar jelas apa yang terkandung dalam judul jurnal diatas, maka penulis perlu membuat penjelasan sehingga pengertian-pengertian istilah yang tercakup dalam judul tersebut dapat dipahami dengan

${ }^{1}$ Ramses Simanjuntak adalah dosen Pendidikan Agama Kristen di STT Nazarene Indonesia, Yogykarta. Pengalaman sebagai fasilitator dan pemimpin jemaat sangat mendukung peran sebagai pendidik dan penggiat pendidikan Kristen. Mendapatkan gelar S.Th dan M.Pd.K di STTII Yogyakarta. Saat ini, ia sedang menempuh pendidikan program S3 di STT Kadesi, Yogyakarta. 
sebaik-baiknya, untuk itu dibawah ini akan penulis coba menjelaskan satu-persatu tentang peristilahan judul tersebut.

Kata "peranan" bentuk dasarnya adalah kata "peran" yang mendapat akhiran "an". Kata "peran" menurut "kamus Umum Bahasa Indonesia" artinya, "pemain sandiwara dan tukang lawak dalam permainan ma'yung" dan kata "peranan’artinya "sesuatu yang menjadi bagian atau yang menjadi pimpinan yang terutama," 2 demikian juga dapat diatikan "yang dimainkan, rol, tugas, kewajiban dan pekerjaan."

Dalam Kamus Bahasa Indonesia, kata "Roh" diartikan sebagai suatu unsur yang ada dalam jasad yang diciptakan Tuhan sebagai penyebab adanya hidup/ kehidupan. Roh juga diartikan sebagai makhluk hidup yang tidak berjasad, tetapi berpikiran dan berperasaan (Malaikat, jin, setan, dsb). Selain itu, roh memiliki arti : Semangat ; spirit. $^{4}$

Manakala arti kata "kudus" didalam kamus Indonesia adalah : Suci ; murni. ${ }^{5}$ Jika kedua kata ini digabungkan menjadi kata "Roh kudus" maka kata ini sudah memiliki arti yang lain. Alkitab juga menyebut Roh kudus sebagai: Roh Allah, Roh kebenaran, Roh Tuhan, Roh Yesus, Roh penghibur. Roh kudus juga dilambangkan sebagai: Nafas, angin, merpati, jari Allah, api.

Kata "iman" dalam Kamus Besar Bahasa Indonesia berarti "kepercayaan yang berkenaan dengan agama Keyakinan kepada Allah."6 Selain itu iman juga diartikan dengan "ketetapan atau keteguhan batin. ${ }^{7 "}$

Manakala kata "percaya" Memiiliki 4 arti di dalam kamus bahasa Indonesia yaitu mengakui atau yakin bahwa sesuatu benar atau nyata, menganggap atau yakin bahwa sesuatu memang benar atau nyata, menganggap atau yakin bahwa seseorang itu jujur, yakin benar

${ }^{2}$ H. Hadiwijono, Iman Kristen (Jakarta: BPK Gunung Mulia, 1982), 384.

3 W.J.S Poerdarminta, "Peran" dalam KamuS Umum Bahasa Indonesia (Jakarta: PN Balai Pustaka, 1984), 735.

${ }^{4}$ Tim Penyusun Kamus Pusat Bahasa, Kamus Bahasa Indonesia (Jakarta: Balai Pustaka, 2002), III: 960.

${ }^{5}$ Ibid, 605.

${ }^{6}$ Ibid, 425.

${ }^{7}$ Ibid. 
atau memastikan akan kemampuan atau kelebihan seseorang atau sesuatu. $^{8}$

\section{Kepribadian Roh Kudus}

Roh Kudus adalah pribadi Allah sendiri, membicarakan topik ini memang sangat menarik. Untuk mengetahui pribadi Roh Kudus ini maka perlu untuk melihat alkitab sebagai satu-satunya sumber yang menjadi dasar kebenaran tentang Roh Kudus tersebut. Ingatlah selalu bahwa ketika orang percaya memadamkan Dia, maka orang percaya menghilangkan kesempatan bagi-Nya untuk memberkati dan menjamah hidup orang percaya dan untuk menjamah hidup orang lain melalui orang percaya. ${ }^{9}$ Seringkali yang menjadi sumber kesalahan dan fanatisme mengenai karya Roh Kudus adalah usaha untuk mempelajari dan memahami karya-Nya tanpa terlebih dahulu mengenalnya secara pribadi. $^{10}$

Kata Roh Kudus dalam bahasa Ibrani adalah "ruah", suatu kata yang kadang-kadang diterjemahkan dengan "angin" atau "nafas."11 Jadi, acuan-acuan Perjanjian Lama kepada nafas Allah atau angin dari Allah (mis Kej 2:7; Yeh 37:9-10) juga dapat mengacu kepada karya Roh Kudus. Roh Kudus itu dilukiskan sebagai nafas Allah yang memberi hidup kepada apa yang diciptakan-Nya.

Roh Kudus tidak mempunyai tubuh bagi dirinya sendiri, kecuali orang-orang yang telah ditebus oleh Kritus dan menyerahkan tubuhnya kepada Dia untuk menjadi tempat kediaman Roh itu. Roh Kudus bukanlah suatu kuasa yang tidak memiliki kepribadian, dan bukan hanya suatu gerakan melainkan Roh Kudus itu adalah Allah sendiri.

${ }^{8}$ Ibid.

9 Benny Hinn. Selamat Datang Roh Kudus (Jakarta: Imanuel Publishing House, 2004), 36.

${ }^{10}$ Ibid, 40.

11 Ibid. 


\section{Roh Kudus Dalam Perjanjian Lama}

Roh Kudus melakukan karya penciptaan pada awal permulaan segala sesuatu yang dijadikan (Kej. 1 : 1; Ibr. $11: 3$ ). Dengan kata lain hal tersebut ingin menyatakan bahwa Roh Kudus adalah sebagai oknum pencipta, jika demikian adanya siapakah yang dapat mencipta? Bukankah Ia itu Allah.

Roh Kudus banyak melakukan pengurapan di Perjanjian Lama. Ia hanya mengurapi orang-orang yang tertentu saja seperti: Yusuf (Kej. 41 : 38), "Yusuf adalah seorang yang penuh dengan Roh Allah." Bezaliel (Kel. 38 : 1 - 6), Bezaliel dipenuhi dengan Roh Hikmat. Musa dan 70 Tua-tua Israel (Bil. 11: 16 - 17) "Maka Aku akan turun dan berbicara dengan ngkau di sana, lalu sebagian dari Roh yang hinggap padamu itu akan Kuambil dan Kutaruh atas mereka, maka mereka bersama-sama dengan engkau akan memikul tanggung jawabatas bangsa itu, jadi tidak usah lagi engkau sendirian memikulnya. " Yosua (Bil. 27 : 18 - 23), "Ambillah Yosua, seorang yang penuh dengan roh letakkanlah tanganmu atasnya." Gideon (Hak. $6: 33$ - 34), "Roh Tuhan menguasai Gideon." Simson (Hak. 13 : 24 - 25), "Lalu perempuan itu melahirkan seorang anak laki-laki dan memberi nama Simson kepadanya, anak itu menjadi besar dan Tuhan nenberkati dia. Mulailah hatinya digerakkan oleh Tuhan di Mahane-Dan yang terletak di Zora dan Esytaol." Raja Saul (1 Sam. 10 : 1; 6 - 10), "Roh Tuhan akan berkuasa atasmu; engkau akan kepenuhan bersama-sama mereka dan berubah menjadi "Manusia lain"." Raja Daud (1 Sam. 16 : 13), "Samuel mengambil tabang tanduk yang berisi minyak itu dan menguapi Daud di tengah-tengah saudara-saudaranya. Sejak hari itu dan seterusnya berkuasalah Roh Tuhan atas Daud. Lalu berangkatlah Samuel menuju Roma." Nabi- nabi (Mik. 3: 8; Za. 4 : 6), "Tetapi aku ini penuh dengan kekuatan dan Roh Tuhan. "Bukan dengan keperkasaan dan bukan dengan kekuatan melainkan dengan Roh Tuhan."

Ada 3 (tiga) aspek pekerjaan Roh Kudus dalam Perjanjian Lama yaitu: Mengusai manusia (2 Taw 24:20), menghinggap manusia (Bil 11:25), memenuhi manusia (Kel 31:3). Menurut kata Dennis dan Ritta bennet dalam buku "The Holy Spirit and You" mengatakan bahwa 
pencurahan Roh Kudus pada zaman Perjanjian Lama sering disebut sebagai pengurapan. ${ }^{12}$

\section{Roh Kudus Dalam Perjanjian Baru}

Pada zaman perjanjian baru, Roh Kudus dicurahkan kepada semua orang percaya; hal ini memang sudah dijanjikan dan direncanakan untuk setiap Orang Percaya di zaman ini (zaman Anugerah atau zaman Roh Kudus)

Pencurahan Roh Kudus pertama yang terjadi secara besarbesaran adalah pada hari Pentakosta:

Kisah Para Rasul 2: 1 - 4: "Ketika tiba hari Pentakosta, semua orang percaya berkumpul di satu tempat. Tiba-tiba turunlah dari langit suatu bunyi seperti tiupan angin keras yang memenuhi seluruh rumah, di mana mereka duduk; dan tampaklah kepada mereka lidah-lidah seperti nyala api yang bertebaran dan hinggap pada masing-masing. Maka "Penuhlah mereka dengan Roh Kudus", lalu mereka mulai berkata-kata dalam bahasa-bahasa lain, seperti yang diberikan oleh Roh Kudus itu kepada mereka untuk mengatakanya"

Kisah Para Rasul 1: 8: "Tetapi kamu akan menerima kuasa, kalau Roh Kudus turun ke atas kamu,dan kamu akan menjadi saksiKu di Yerusalem, dan di seluruh Yudea dan Samaria dan sampai ke ujung dunia." Contoh-contoh lain tentang pencurahan Roh Kudus pada Gereja mula-mula adalah: Orang Percaya di Samaria (Kis. 8 : 17), "kemudian keduanya menumpangkan tangan di atas mereka, lalu mereka menerima Roh Kudus. " Kornelius dan semua orang yang lain (Kis. 10 : 44), Ketika Petrus sedang berkata demikian, turunlah Roh Kudus ke atas semua orang yang mendengarkan pemberitaan itu. " Orang-orang percaya di Efesus (Kis. 19 : 6 - 7), "Dan ketika Paulus menumpangkan tangan di atas mereka, turunlah Roh Kudus ke atas mereka dan mulailah mereka berkata-kata dalam bahasa roh dan bernubuat."

Manusia itu terdiri dari 3 (tiga) unsur yaitu: Tubuh, Jiwa dan Roh. Oleh karena itu manusia memiliki unsur roh, maka manusia itu dapat menerima Roh Kudus dengan membuka hati mereka. Roh manusia dapat mempengaruhi setiap karakter manusia. Kalau rohnya

${ }^{12}$ Ritta Bennet, The Holy Spirit and You (Zondervan: t.t), 15. 
dipimpin oleh Roh Kudus, maka sifat orang tersebut akan dipengaruhi oleh Roh Kudus untuk menjadi sama seperti Kristus yang bersifat lemah lembut. Apabila rohnya dikuasai oleh Iblis, maka karakter orang tersebut akan sama seperti Iblis.

\section{Tugas Dan Fungsi Roh Kudus}

Roh Kudus sangat memainkan peranan penting dalam kehidupan manusia sehari-hari. Ia berperang untuk memberi tuntunan kepada orang percaya supaya hidup dalam takut akan Tuhan. Untuk itulah Roh Kudus diutus kepada manusia supaya kehidupan mereka berkenan kepada Tuhan.

Tujuan Roh Kudus dicurahkan kepada manusia adalah bertujuan supaya manusia memiliki karakter Allah dan memiliki persekutuan yang indah bersama dengan Tuhan. Bahkan lebih daripada itu adalah supaya manusia menjadi anak-anak Allah karena dipimpin oleh Roh Allah (Rm 8:14).

Ketika orang percaya membuka hati mereka kepada Tuhan untuk menerima Roh-Nya maka Roh Kudus itu menguasainya. Pada saat yang bersamaan, manusia akan menjadi satu dengan Kristus. Seperti yang terdapat dalam diktat School Of Christ yang menuliskan bahwa: "Ketika kita menerima Roh Kudus, saat itu juga kita bersatu dengan Kistus ; karena, saat itu juga kita bersatu dengan tujuan Allah tentang Kristus, melalui dan oleh Roh Kudus. Kita bukan hanya tujuan Kristus, tetapi juga telah menjadi alat dimana tujuan itu digenapi."

Kata Smith Wigleswoth: "Roh Kudus tidak akan pernah datang sampai sebuah tempat itu dipersiapkan bagi-Nya. Roh Kudus hanya dapat masuk kedalam kita (Bait-Nya) ketika kita sepenuhnya berserah sepenuh kepada-nya, karena Roh "tidak akan diam di dalam apa yang dibuat oleh tangan manusia" (Kis 7: 48). Tatapi "pada loh-loh daging yaitu di dalam hati manusia" (2 Kor 3: 3). ${ }^{14}$ Dalam 1 korintus $2: 14$ mengatakan bahwa "manusia duniawi tidak dapat menerima Roh Allah".

${ }^{13}$ Bennet, The Holy Spirit And You, 17.

${ }^{14}$ Smith Wigleswoth, Jamahan Roh Kudus (Bandung: Revival Publishing house, 2002), 92 . 
Banyak orang percaya yang salah menggunakan baptisan Roh Kudus ini dengan mempamerkan dirinya kepada sesama dengan kata bahwa ia sudah menggenapi Firman Allah. Padahal sifat dan karakter Roh Kudus adalah kerendahan hati.

\section{Karunia-Kaunia Roh Kudus}

Setiap orang percaya yang dipenuhi Roh Kudus pasti memiliki setidak-tidaknya satu karunia, tapi bersyukur pula jika memiliki karunia lebih dari satu. Karunia itu diberikan kepada manusia saat dilahirkan oleh Roh Kudus atau mengalami proses kelahiran kembali.

Dalam 1 Korintus 12:8-10 dicantumkan 9 karunia Roh yang dapat dikatrgorikan kepada 3 (tiga) kelompok yaitu: Pertama adalah, karunia pengetahuan rohani atau yang disebut dengan revelation, di dalamnya mencakup: perkataan hikmat, perkataan marifat, membedakan segala roh.

Kedua adalah karunia Kuasa atau yang disebut dengan power, di dalamnya mencakup: kuasa iman, penyembuhan ilahi, perbuatan mujizat.

Ketiga adalah karunia ucapan atau ilham atau yang disebut dengan inspiration, di dalamnya mencakup: nubuat, karunia lidah , mengartikan makna lidah.

Selain daripada yang terdapat di 1 Korintus 12: 8-10, karunia Roh juga terdapat juga terdapat di dalam kitab Roma 12: 38 dan Ef $4: 11$.

\section{Buah Roh}

Buah Roh terdapat 9 jenis seperti yang terdapat di dalam Galatia 5:22-23, yang meliputi: Kasih, sukacita, damai sejahtera, kesabaran, kemurahan, kebaikan, kesetiaan, kelemahlembutan dan penguasaan diri. Kesembilan buah Roh ini berpengaruh untuk membangun karakter orang percaya supaya menjadi lebih berkenan kepada Tuhan daripada cara hidup yang sebelumnya.

Buah Roh ini dapat diartikan sebagai berikut, yaitu: Kasih. Kasih di dalam bahasa Yunani ada 5 (lima) arti yaitu: Agape: kasih 
Allah, Fileo: Kasih persahabatan, Storge: Kasih kekeluargaan, Eros: Kasih hawa nafsu atau berahi, Thelo: Kasih terhadap diri sendiri.

Sukacita. Rasul Paulus dengan tegas mengajarkan kepada semua orang tanpa terkecuali supaya senantiasa bersukacita di dalam Tuhan (Flp 4:4) karena itulah yang dikehendaki oleh Allah di dalam manusia (1 Tes. $5: 16$ - 18).

Damai sejahtera. Manusia sering kali gelisah dan binggung untuk menghadapi sesuatu di dalam hidupnya. Hal ini memang wajar bagi manusia tetapi bukan berarti bahwa masalah ini dapat membuat hidup ini kehilangan damai sejahtera.

Yesus berkata dalam Yohanes 16 : 33 "Semua ini Kukatakan supaya kamu beroleh damai sejahtera dalam Aku, dalam dunia kamu menderita penganiayaan, tetapi kuatkanlah hatimu, Aku telah mengalahkan dunia." Jadi tidak ada alasan lagi bagi manusia untuk tidak memiliki damai sejahtera di dalam diri mereka, karena Yesus telah mengalahkan dunia ini.

Kesabaran. Kesabaran adalah suatu sifat ketahanan untuk menghadapi tekanan-takanan hidup yang menyebabkan penderitaan. Banyak orang cenderung tidak tenang dan gelisah ketika menghadapi masalah. Tetapi jika ia adalah orang yang sudah mempercayakan semuanya kepada Tuhan maka ia akan tetap sabar untuk menghadapi segala sesuatu yang dihadapinya.

Kemurahan. Kemurahan adalah sifat ilahi yang berkaitan dengan anugerah, kebaikan dan kesabaran. Memang Allah itu adil dan bebar tetapi Ia hurus menghukum dosa dan pelanggaran. Namun Allah juga adalah Allah yang murah hati. Ia tidak segera menjatuhkan hukuman. Allah mengajar manusia supaya mau belajar dari Dia yang selalu memaafkan pelanggaran manusia dan memiliki kaakter ini dari Dia.

Kebaikan. Alkitab mengatakan bahwa "Allah itu baik" maka tidaklah mustahil bagi anak-anak Tuhan untuk memiliki sifat dan karakter Allah. Dalam Efesus 5:8-9 mengatakan: "Hiduplah sebagai anak-anak terang yang berbuahkan kebaikan, keadilan dan kebenaran." Ketiga hal ini adalah sifat yang dimiliki oleh anak-anak Terang.

Kesetiaan. Kesetiaan adalah sifat Ilahi dalam hidup orang percayasebagai buah Roh Kudus. Dengan memiliki kesetiaan ini, maka orang percaya dapat bertahan untuk melayani Tuhan, mengiring Tuhan 
dalam segala kesulitan dan tantangan walaupun dilanda dengan banyak permasalahan yang mengoncang iman. Dalam kitab Wahyu 2:10 menuliskan bahwa " Hendaklah engkau setia sampai mati, dan Aku akan mengaruniakan kepadamu mahkota kehidupan".

Kelemah lembutan. Orang yang lemah lembut ini adalah orang yang tidak keras hati dan sombong. Ia mengenai dirinya seniri sebagaimana adanya. Ia merasa kecil di hadapan Allah dan hanya bergantung kepada anugerah Allah (1 Kor 15-10). Contoh tokoh alkitab yag menunjukkan bahwa meeka adalah tokoh yang lemah lembut adalah: Tuhan Yesus.

Peguasaan diri. Kitab Amsal mengatakan bahwa: "Orang yang menguasai dirinya melebihi orang yang merebut kota" (Ams 16:32). Hanya Roh Kudus saja yang dapat memampukan manusia untuk menguasai diri di dalam segala hal.

Kesembilan buah Roh ini dapat diklasifikasikan ke dalam 3 kelompok yaitu: Kasih, sukacita dan damai sejahtera (Diri Sendiri), kebaikan, kemurahan dan kesabaran (Sesama) kesetiaan, kelemah lembutan dan penguasaan diri (Allah).

\section{Kesimpulan}

Roh Kudus bukan hanya sekedar pengaruh atau kuasa sematamata. Ia adalah Allah itu sendiri. Terbukti bahwa Allah itu adalah Roh. Ia tidak bias dibatasi dengan akal budi manusia. Manusia mengenal Allah dan bersekutu dengan Allah melalui roh dan jiwa manusia, dan bukannya dengan pancaindera manusia.

Roh Kudus tidak mempunyai tubuh bagi dirinya sendiri, kecuali orang-orang yang telah ditebus oleh Kritus dan menyerahkan tubuhnya kepada Dia untuk menjadi tempat kediaman Roh itu. Roh Kudus bukanlah suatu kuasa yang tidak memiliki kepribadian, dan bukan hanya suatu gerakan melainkan Roh Kudus itu adalah Allah sendiri.

\section{Iman dan hidup Orang Percaya}

Ketika orang percaya menjadi umat Tuhan maka pada saat itu dia disebut sebagai orang beriman. Hal ini tidak terlepas dari peranan Roh Kudus sebagai oknum yang memperanakkan orang tersebut untuk 
menjadi orang percaya. ${ }^{15}$ Untuk itu diharapkan bahwa setiap orang yang sudah menjadi percaya hidupnya harus dipenuhhi oleh Roh, karena itu adalah tanda-tanda orang beriman kepada Yuhan Yesus. ${ }^{16}$

Banyak orang percaya mengatakan, bahwa ia mengandalkan Tuhan dan menaruh harapannya kepada Tuhan. Tetapi, seringkali ungkapan itu hanyalah sekedar kata-kata dan tidak lebih daripada itu. Sebab, pada kenyataannya dalam kehidupan sehari-hari, mereka tidak menunjukkan sikap dan cara hidup yang menunjukkan bahwa mereka sungguh-sungguh berharap kepada kepada Tuhan. Dan merupakan suatu hal yang sangat menyedihkan untuk melihat orang-orang yang mengaku bahwa dirinya Kristen, namun tidak memiliki kehidupan dan kuasa. $^{17}$

Dalam Kitab Roma 1:17, mengatakan Bahwa "Orang benar akan hidup oleh iman". Setiap orang yang hidupnya bersandar kepada Allah akan dapat dilihat dari sikap dan cara hidupnya sehari-hari. Salah satu tanda kehidupan orang yang sungguh-sungguh bersandar kepada Allah adalah jika ia memiliki kehidupan doa dan ketekunan untuk membaca firman Tuhan.

\section{Definisi Iman}

Betapa singkat dan sederhananya kata itu! Tetapi adakah manusia yang dapat benar-benar mengukur atau menjabarkan daya tenaga dahsyat yang terkandung di dalamnya? ${ }^{18}$ Iman seringkali dipandang begitu saja dan kurang diberi perhatian yang serius. Padahal hidup manusia haruslah bergerak dari iman kepada iman. Alkitab berkata iman adalah dasar dari segala sesuatu. Jadi apapun yang diperbuat, iman adalah awal dari semunya. Iman bukanlah tempat kekurangan melainkan kelimpahan. ${ }^{19}$

${ }^{15}$ Tom Sappington, Diktat Pneumatologi (STII Yogyakarta: 1998), 84.

${ }^{16}$ Stephen Tong, From Faith to Faith (Surabaya: Momentum, 2001), 15.

17 Smith Wiglesworth, Urapan Roh-Nya (Bandung: Rivival Publishing House, 2000), 110.

18 Derek Prince, Iman Yang Olehnya Kita Hidup (Jakarta: Yayasan Perkabaran Injil 1993), 7.

${ }^{19}$ Ibid, 27. 
Iman adalah sifat Allah yang mendasar. Iman itu sebenarnya adalah Firman Allah sendiri. ${ }^{20}$ Selain itu, iman merupakan landasan kehidupan orang kekristenan (Ibr 11:1). Dan pertanyaannya, iman yang bagaimana yang tumbuh dalam kehidupan manusia saat ini? Jika kita memiliki iman yang benar, sudahlah pasti hidup kita diwarnai dengan kebenaran Tuhan. Sebaliknya jika kita memiliki iman yang salah, hidup kita sarat dengan segala bentuk kegagalan. Iman percaya setiap orang di dalam Tuhan akan menyanggupkan orang percaya untuk tetap kuat dan bertahan di tengah-tengah situasi dunia yang semakin hari semakin berat rasanya. Iman kepada Kristus juga akan memampukan setiap manusia untuk terus bergerak bahkan mengalami kuasa dan keajaibanNya.

Iman memiliki tindakan. Alkitab mengatakan bahwa orang akan hidup oleh iman yang artinya bergantung sepenuhnya kepada Allah yang merupakan sumbur kehidupan. Hal inilah yang membuat banyak orang percaya hidup dalam sukacita sekalipun mereka tidak memiliki banyak harta. Derek Prince mengatakan bahwa iman adalah sesuatu yang tidak ternilai harganya. Tiada suatupun yang dapat menggantikannya. Tanpa iman tak mungkin orang menghampiri Allah, tak mungkin untuk berkenan kepada-Nya dan tak mungkin untuk menerima kehidupannya. ${ }^{21}$

Hidup oleh iman bukan berarti kita tidak bekerja atau berusaha. Justru karena beriman Tuhan memberkati usaha dan pekerjaan kita. Alkitab berkata bahwa iman timbul dari pendengaran dan pendengaran akan firman Tuhan. Melalui pergumulan hidup dan penderitaan biasanya iman akan timbul kalau ia mulai percaya dan berpegang pada janji-janji Allah.

Dalam buku Ensiklopedi Alkitab Masa Kini mengatakan bahwa: Iman ialah sikap yang di dalamnya seseorang melepaskan andalan pada segala usahanya sendiri untuk mendapatkan keselamatan, entah itu kebajikan, kebaikan susila atau apa saja kemudian mengandalkan Yesus Kristus.dan mengharap hanya dari Dia segala sesuatu yang dimaksud dengan 'keselamatan'. ${ }^{22}$

${ }^{20}$ Wigglesworth, Urapan Roh-Nya, 24.

${ }^{21}$ Prince, Iman Yang Olehnya Kita Hidup, 89.

${ }^{22}$ L. L. Moris, "Iman” dalam Ensiklopedi Alkitab Masa Kini, pen. M. H. Simanungkalit (Jakarta: Yayasan Komunikasi Bina Kasih/OMF, 1992), 431. 
Iman tidak berarti menerima hal-hal tertentu sebagai sesuatu yang benar, tetapi menyerahkan diri (mengandalkan diri) kepada Yesus Kristus. Melalui ini, dapat disimpulkan bahwa Iman merupakan dasar kekristenan. Ini menandakan bahwa iman bukanlah sesuatu yang berlalu, tetapi sesuatu yang berlangsung secara terus-menerus. Smith Wirlesworth mengatakan bahwa "manusia tidak akan pernah menjadi perkakas Allah yang penting jika ia belum berani berisiko berhadapan dengan kemustahilan" 23

\section{Agama dan Iman}

Dalam dunia ini terdapat begitu banyak agama atau kepercayaan yang dipercayai oleh setiap manusia. Ada yang percaya kepada alam semesta atau yang disebut sebagai kepercayaan "Aninisme" yaitu kalau tidak sujud menyembah kepada alam semesta maka akan terjadi malapetaka yang akan menimpa mereka. Selain itu, ada juga yang percaya bahwa di dunia ada penguasa-penguasa yang berkuasa seperti contoh tuhan, dewa-dewa, ilah-ilah atau patung-patung dan sebagainya untuk menjadi sembahan mereka.

Dan di antara semua agama, agama Kristen adalah agama yang percaya kepada Yesus Kristus sebagai Tuhan dan Juruselamat pribadi mereka. Stephen Tong berkata bahwa: "Agama Kristen adalah agama yang berbeda dari semua agama secara kualitatif, dan bukan secara kuantitatif." 24 Agama Kristen merupakan agama yang unik karena agama ini hidup dalam anugerah Allah melalui iman. Iman merupakan fondasi kekristenan. Orang percaya hidup di depan Allah bukan dengan uang, bukan dengan jasa, atau bukan dengan kebajikan melainkan dengan iman yang tertuju kepada Yesus Kristus. Orang Kristen memang hidup dengan uang, jasa, kebajikan. Tetapi jauh daripada itu, orang percaya lebih lebih tertuju kepada iman kepada Yesus Kristus.

\footnotetext{
${ }^{23}$ Wiglesworth, Urapan Roh-Nya, 4-5.

${ }^{24}$ Tong, From Faith To Faith, 6.
} 
Menurut Perjanjian Baru, terdapat 3 (tiga) golongan orang Kristen yaitu: yang dewasa secara rohani, yang tidak dewasa secara rohani, dan yang rohaninya mundur. Kemungkinan yang tragis bagi seseorang percaya ialah tidak mencapai kedewasaan secara rohani. Dewasa rohani ini juga bercerita tentang dewasanya iman seseorang manusia.

Banyak di antara orang Kristen yang memiliki iman kepada Tuhan. Namun sering kali mereka memiliki iman yang salah. Terdapat 4 jenis iman yang salah dan diantara iman yang salah itu adalah:

\section{Iman berdasarkan penglihatan}

Banyak orang yang mahu percaya kepada sesuatu jika ia sudah melihatnya. Iman seperti ini adalah iman yang dibangun di atas penglihatan atau apa yang bisa dilihat secara kasat mata. Jadi apa yang tidak dilihat oleh mataakan menjadi sesuatu yang sulit untuk dipercayai.

Sebagai contoh, Thomas yang tidak percaya kepada apa yang dikatakan oleh murid-murid Tuhan Yesus ketika mereka mengatakan Yesus telah bangkit dari antara orang mati.

\section{Iman berdasarkan pengalaman}

Jika ada yang mengatakan bahwa "saya tidak mengalami apaapa saya tidak akan percaya" atau "jika saya alami ,saya akan beriman". Ini berarti bahwa iman ini didasarkan dengan pengalaman.

Memiliki iman seperti ini adalah tidak baik, karena jika pengalamannya berubah, maka iman yang dibangun di atas dasar pengalaman akan terombang-ambingkan.

\section{Iman berdasarkan bukti}

Manusia sering menginginkan bukti terhadap sesuatu untuk percaya. jika tidak ada bukti maka adalah susah untuk percaya. 


\section{Iman berdasarkan logika}

Memikirkan sesuatu memang tidak salah melainkan wajar dan bagus. Tetapi jika ingin beriman namun berpikir bahwa apakah itu logis atau masuk akal, maka akan membuat iman itu menjadi tidak berfungsi.

\section{Harapan dan kehidupan beriman}

Semua orang pasti memiliki harapan terhadap sesuatu untuk diraih. Dalam Kamus Besar Bahasa Indonesia, harapan diartikan sebagai: Keinginan untuk menjadi kenyataan. Baik muda maupun tua, baik miskin ataupun kaya, pengharapan pasti dimiliki oleh semua orang untuk meraih sesuatu yang akan menjadi kenyataan.

Harapan tidak akan terjadi atau terkabul jika manusia tidak mau bertindak dan berusaha untuk mencapai keinginannya yang akan menjadi kenyataan karena iman adalah cara manusia untuk mendekati Allah (Yak 1:6, 5:15) dan pebuatan manusia akan mendemonstrasikan realitas dari iman (Yak 2:18).

Dalam buku Smith Wigglesworth yang berjudul Urapan RohNya, mengatakan:

Saudara tidak dapat meraih apapun jika tertidur. Dunia ini selalu terjaga. Oleh karena itu, kita juga harus selalu terjaga untuk meraih apa yang Allah telh sediakan bagi kita. Bangun dan raihlah! Berapa banyak yang bisa kita raih? Kita tahu bahwa kerinduan Allah untuk memberkati kita adalah jauh lebih besar daripada kerinduan kita untuk menerima sesuatu dari Allah. $^{25}$

Firman Tuhan dengan jelas mengajarkan bahwa kemenangan yang mengalahkan dunia adalah iman kita (1Yoh 5:4). Dan tidak hanya itu saja, tetapi juga untuk melawan dan mengalahkansi Iblis (1 Pet 5:9).

Iman itu timbul dari pendengaran dan pendengaran akan Firman Tuhan. Manusia tidak mungkin memiliki iman dengan begitu saja jika

\footnotetext{
${ }^{25}$ Tong, From Faith To Faith, 6.
} 
ia tidak mendengarkan Firman Tuhan dan merenungkannya. Mendengan Firman Tuhan tetapi tidak merenungkan, maka Firman itu akan menjadi sia-sia dan tidak berarti dalam kehidupan ini. Sehingga iman yang diharapkan untuk timbul menjadi sulit untuk diperoleh karena tidak menerima Firman itu dangan baik.

Realita di sekitar kita menunjukkan bahwa ada banyak orang yang mengetahui sekelumit saja tentang Firman Tuhan. Padahal kalau orang Kisten hanya membaca sedikit saja tentang kebenaran Firman Tuhan, maka semakin terbataslah pula cakupan iman yang akan diperolehinya. Hal ini terjadi karena manusia hanya mempercayai apa yang diketahuinya. Jadi seberapa banyak kebenaran Fiman Tuhan yang kita ketahui, maka sedemikian pulalah kadar iman yang akan kita perolehi.

Banyak orang yang berharap untuk memiiki kehidupan yang beriman, namun harapan itu sering menjadi mimpi yang tidak terwujudkan karena tidak dapat menjadi mempraktekkan iman dengan baik seperti yang dikatakan Tuhan Yesus. Yesus sering kali mengajarkam murid-murid-Nya supaya memiliki iman. Tidak dikatakan iman seperti apa yang harus dimiliki oleh mereka. Baik itu iman yang besar, iman yang kuat atau iman yang teguh, tidak seperti demikian. Melainkan dikatakan "sekiranya kamu memiliki iman sebiji sesawi saja kamu dapat berkata kepada gunung ini pindah dari tempat ini ke sana - maka gunung ini akan pindah..." (Mat 17: 20).

Allah tidak melihat iman sebesar apa yang dimiliki oleh manusia, tetapi apa yang dilihat-Nya adalah adakah iman itu di hati umat-Nya (Luk 7: 9). Iman itu tidak berasal dari manusia tetapi merupakan pemberian dari Allah. ${ }^{26}$

Biji sesawi adalah yang paling kecil dari dari segala jenis benih. Yesus memperumpamakan iman dengan biji sesawi. Dengan kata lain, menurut Yesus yang penting bukanlah besar (berapa banyaknya) iman seseorang melainkan kadar iman yang dimilikinya. ${ }^{27}$

Dalam kitab Markus 11:23 Yesus bukan saja berbica kepada para murid yang hadir pad waktu itu: "Jika kamu percaya..." tetapi Ia mengatakan "barangsiapa". Dengan demikian janji-Nya itu sebenarnya berlaku juga secara umum bagi semua orang percaya.

\footnotetext{
${ }^{26}$ Prince, Iman Yang Olehnya Kita Hidup, 31.

27 Ibid, 34.
} 


\section{Tinjauan Teologis Makna Kata Orang Percaya}

Pendapat umum mengatakan bahwa Gereja itu adalah tempat Ibadah Orang Kristen. Dalam kamus besar bahasa Indonesia, kata Gereja diartikan sebagai: Gedung (rumah) tampat berdoa dan melakukan upacara agama Kristen. ${ }^{28}$

Kata Inggris untuk church berhubungan dengan kata Scottish kirk dan kirche dalam bahasa Jerman. Semua istilah ini berasal dari kata Yunani kuriakon. Bentuk ajektif netral dari kurion (Lord), berarti "milik dari Tuhan." ${ }^{29}$ Kata Inggris church juga merupakan terjemahan dari kata Yunani ekklesia, yang berasal dari kata $e k$, berarti "keluar dari", dan kaleo yang berarti "memanggil". Jadi gereja adalah "seuatu kelompok yang dipanggil keluar." ${ }^{30}$

Ensiklopedi menuliskan bahwa: "Kata Ekklesia juga dipakai di kalangan Yahudi (LXX) bagi 'Jemaat Israel' yang dibentuk di Sinai dan dikumpulkan di depan hadirat Allah pada hari-hari raya tahunan, yakni pengantara yang ditunjuk kepada Allah untuk menjadi wakil umat." ${ }^{\text {"31 }}$

Istilah kata ekklesia ini mulai digunakan pertama kali pada zaman Perjanjian Baru setelah kenaikan Yesus Kristus ke Sorga, dimana orang percaya mengadakan pertemuan di suatu tempat untuk berkumpul dan memuji Tuhan. Selain kata ekklesia, istilah kata Qahal juga sering digunakan di dalam Perjanjian Baru untuk mengartikan sekelompok kumpulan orang dari suatu tempat untuk beribadah atau gerakan bersama-sama. ${ }^{32}$ Di samping itu ensiklopedi juga menuliskan bahwa bagi Israel, sinagoge akan merupakan tempat kudus dalam

${ }^{28}$ Tim Penyusun Kamus Besar Bahasa Indonesia, "Gereja” dalam Kamus Besar Bahasa Indonesia, 357.

${ }^{29}$ Robert L. Saucy, The Church in God's Program (Chicago: Moody, 1972), 11.

${ }^{30}$ Paul Enns, The Moody Handbook of Theology (Malang: Literatur SAAT, 2003), 431.

${ }^{31}$ D. W. B. Robinson, “Gereja” dalam Ensiklopedi Alkitab Masa Kini, pen. Harun Hadiwijono (Jakarta: Yayasan Komunikasi Bina Kasih/OMF, 1992), I: 332.

${ }^{32}$ C. L. Feinberg, "Sinagoga atau Rumah Ibadat” dalam Ensiklopedi Alkitab Masa Kini, pen. M. H. Simanungkalit, peny. H.A. Oppusunggu (Jakarta: Yayasan Komunikasi Bina Kasih/OMF, 1992), II: 408. 
ukuran mini pengganti Bait Suci yang hilang. ${ }^{33}$ Sinagoge tidak memiliki Mezbah tetapi Bait Suci ada.

Sebelum penggunaan kata ekklesia dan kata sinagoge di dalam Perjanjian Baru, kata 'Qahal' sering digunakan dalam Perjanjian Lama dan kata ini muncul sebanyak 123 kali. ${ }^{34}$ Kata qahal berarti 'berkumpul bersama' untuk tujuan keagamaan (Bil 10:7). ${ }^{35}$

Buku Smith Wigglesworth mengatakan bahwa Gereja adalah tubuh Kristus. ${ }^{36}$ Gereja tidak hanya gedung saja tetapi adalah juga Umat-Nya yang berkumpul untuk bersekutu dengan Allah.

Kitab Kisah Para Rasul 2:1-4 menceritakan lahirnya Gereja yang pertama yaitu:

Ketika tiba hari Pentakosta, semua orang percaya berkumpul di suatu tempat. Tiba-tiba turunlah dari langit suatu bunyi seperti tiupan angin keras yang memenuhi seluruh rumah, dimana mereka duduk; dan tampaklah kepada mereka lidah-lidah seperti nyala api yang bertebaran dan hinggap pada mereka mesing-masing. Maka penuhlah mereka dengan Roh Kudus, lalu mereka mulai berkata-kata dalam bahasa-bahasa lain, seperti yang diberikan oleh Roh itu kepada mereka untuk mengatakannya.

Biasanya konsep tentang gereja difokuskan kepada 2 (dua) yaitu: Gereja Universal dan gereja lokal. Gereja Universal biasanya diartikan kepada semua orang percaya yang ada di bumi dan maupun yang ada di Sorga. Manakala gereja lokal diartikan kepada sejumlah jemaat yang berhimpun disuatu tempat untuk bersekutu terus-menerus seperti gereja yang ada di Yerusalem (Kis 8:1; 11:22), di Asia Kecil (Kis 16:5), di Roma (Rm 16:5), di Korintus ( 1 Kor 1:2; 2Kor 1:1), di Galatia ( Gal 1:2), di Tesalonika ( 1 Tes 1:1), dan di rumah Filemon ( Fil 2).

${ }^{33}$ Ibid, M. T. Fermer, "Temu, Pertemuan" dalam dalam Ensiklopedi Alkitab Masa Kini, pen. J. M. Pattiasina, peny. H.A. Oppusunggu (Jakarta: Yayasan Komunikasi Bina Kasih/OMF, 1992), II: 461.

${ }^{34}$ Ibid.

35 Ibid.

${ }^{36}$ Wiglesworth, Urapan Roh-Nya, 229. 


\section{Peranan Roh Kudus Dalam Pertumbuhan Iman Orang Percaya}

Roh Kudus mulai berkarya dengan dahsyat pada zaman para Rasul pada waktu sesudah kenaikan Yesus Kristus ke Sorga. Sebelum zaman para Rasul, Roh Kudus pada zaman Perjanjian Lama juga berkarya hanya tidak seperti yang Ia lakukan pada zaman para Rasul pada hari Pentakosta dan saat memberitakan injil kepada semua dengan disertai tanda-tanda mujizat yang luar biasa.

Roh Kudus memang berkarya di zaman Perjanjian Lama tetapi hanya kepada orang-orang tertentu saja. Dan perbedaannya dengan yang di Perjanjian Baru adalah Roh Kudus di Perjanjian Lama mengurapi orang-orang tertentu untuk memegang suatu tanggung jawab atau tugas yang Tuhan percayakan kepadanya. Roh Kudus dalam Perjanjian Lama hanya melakukan 3 (tiga) aspek pekerjaan yaitu: Menguasai manusia (2 Taw 24: 20), menghinggapi manusia (Bil 11: 27) dan memenuhi manusia $(\operatorname{Kel} 31: 3)^{37}$

Berbeda dengan apa yang terjadi pada zaman Perjanjian Baru terhadap para Rasul dan pengikut-pengikut Tuhan yang lain. Roh tidak hanya dicurah kepada orang-orang tertentu seperti yang terdapat di kitab Perjanjian Lama, melainkan Roh Kudus itu dicurahkan kepada semua orang tanpa terkecuali seperti apa yang telah terjadi di dalam kitab Kisah Para Rasul di mana orang non Yahudi yang baru percaya juga menerima pencurahan Roh Kudus.

Roh Kudus yang tercurah kepada 120 orang pada hari Pentakosta dan seterusnya kepada semua yang percaya tidak hanya dikuasai, dihinggap dan dipenuhi oleh Roh Kudus, tetapi diperlengkapi dengan kuasa untuk melakuan banyak mujizat dan menjadi saksi kepada semua orang (Kis 1:8). Markus mengatakan bahwa mereka akan disertai dengan tanda-tanda yang supranatural dan dahsyat (Mrk 17: 18) karena Roh Kudus ada di dalam mereka.

Ketika bertemu dengan Roh Kudus dan dibaptis di dalam Dia, maka segala sesuatu akan berubah di dalam hidup ini sehingga ada

37 Bethany School of Ministry (Buku Paket SOM Gereja Bethany Surabaya, Nginden: 2008), 19. 
kehausan akan Tuhan Yesus untuk mengenai-Nya lebih dalam lagi. Sifat dan sikap yang lama akan dijadikan-Nya menjadi sama seperti Yesus dan akan menjadi baru.

Saat Roh Kudus datang ke dalam manusia, manusia itu akan mengalami perubahan yang drastic. Mungkin selama ini ia tidak dapat bersaksi, minder, malu dan sebagainya terhadap yang lain. Namun ketika Roh Kudus ada dalam dirinya, maka ia akan menjadi orang yang luar biasa yang dipakai oleh Tuhan untuk menjadi alat-Nya.

\section{Menginsafkan Orang Dari Dosa}

Pada mulanya, ketika manusia diciptakan oleh Allah yaitu Adam dan Hawa di dunia ini, mereka adalah manusia yang sempurna dan tanpa dosa. Mereka diciptakan dan ditempatkan di Taman Eden. Kehidupan Adam dan Hawa dengan Allah terjalin dengan sangat baik dan dapat dikatakan bahwa mereka sering bergaul dengan Allah.

Manusia hanya dapat bergaul dengan Allah jika kehidupannya benar dan berkenan dengan Dia. Namun kehidupan mereka terputus karena tidak taat kepada Allah karena memilih kepada kehendak mereka sendiri untuk memakan buah larangan tentang yang baik dan yang jahat. Dan seketika itu juga mata mereka mulai terbuka dan mengetahui tentang yang apa baik dan yang jahat.

Sejak dari itulah, maka manusia sudah berada dalam kehidupan yang berdosa karena diperanakkan di dalam dosa melalui Adam dan Hawa. Setiap orang percaya akan mengakui bahwa persoalan dosa secara serius melawan dirinya dengan rintihan setelah ia percaya kepada Tuhan Yesus. Pada masa lalu ketika manusia masih menjadi orang-orang yang tidak beriman, "kami hidup dalam hawa nafsu daging dan menuruti kehendak daging dan pikiran kami yang jahat" (Efs 2: 3). Pada wakyu itu manusia tidak menerima hidup kekal dan pemulihan dari Tuhan Yesus, dosa menjadi suatu masalah kepada manusia.

Dalam pikiran orang percaya terdapat beberapa pertanyaan seperti: Tak dapatkah saya menahan diri dari jatuh ke dalam dosa berkali-kali sekalipun saya telah diselamatkan? Tidakkah saya mempunyai kuasa untuk mengalahkan dosa? 
Roma 7 dan 8 ada kaitannya dengan pertanyaan-pertanyaan ini. Dan Roma 6 mengajarkan tentang perubahan dasar yang berlangsung atau terjadi ketika seorang perfcaya kepada Yesus Kristus:

Atau tidak tahukah kamu, bahwa kita semua yang telah dibaptis dalam Kristus, telah dibaptis dalam kematianNya? Dengan demikian kita telah dikuburkan bersama-sama dengan Dia oleh baptisan dalam kematian, supaya, sama seperti Kristus telah dibangkitkan dari antara orang mati oleh kemulian Bapa, demikian juga kita akan hidup dalam hidup yang baru. Sebab jika kita telah memjadi satu dengan apa yang telah menjadi kematianNya, kita juga akan memjadi satu dengan apa yang apa satu yang sama dengan kebangkitanNya. Karena kita tahu,bahwa manusia lama kita telah turut disalibkan, supaya tubuh dosa kita hilang kuasanya, agar kita jangan menghambakandir lagi kepada dosa. Sebab siapayang telah mati, ia telah bebas dari dosa.

Seseorang yang telah menerima Yesus Kristus sebagai Juruselamat pribadi berlainan sekali dengan seorang yang hanya menerima keagamaan Kristen atau suatu pola moral. Alkitab juga memerintah manusia untuk mengubah sikap dan pemikiran mereka: “ Demikianlah hendaknya kamu memandangnya: bahwa kamu telah mati bagi dosa, tetapi kamu hidup bagi Allah dalam Kristus" (Rm 6: 11). Manusia harus percaya "siapa yang ada dalam Kristus, ia adalah ciptaan baru (2 Kor 5: 17).

\section{Menunjukkan jalan Kebenaran}

Roh Kudus sangat berperan penting dalam menuntun setiap orang kepada jalan kebenaran. Manusia sering kali jatuh bangun karena belum mengetahui jalan kebenaran atau sama sekali belum mengenal kebenaran. Di dalam dunia ini ada dua jalan yaitu: jalan menuju kepada kebinasaan atau maut, dan jalan menuju kepada keselamatan.

Banyak orang pada zaman ini berusaha mencari keselamatan tetapi mereka tidak menemukan jalan keselamatan dan tidak tahu kepada siapa mereka pergi uatuk menemukan keselamatan bagi jiwa mereka. 
Dalam dunia ini begitu banyak ajara dan agama. Semua agama yang ada di dunia mengajarkan nilai-nilai moral yang baik tetapi tidak mengajakan tentang keselamatan yang sesungguhnya atau secara detail. Ada agama yang mengatakan bahwa setelah kematian manusia akan beringkarnasi. Selain itu, ada juga yang mengajakan tentang keselamatan melalui setiap perbuatan amal manusia selama ia hidup di bumi.

Memang benar dengan setiap agama yang mengajarkan tentang nilai moral kepada setiap orang. Tetapi jauh daripada itu yang harus diketahui oleh setiap manusia adalah kehidupan setelah kematian yaitu penghakiman yang menentukan akhir hidup mereka untuk selamalamanya.

Melalui Roh Kuduslah, maka setiap orang yang telah menerima Dia akan mengetahui keberadaan mereka dalam mencari jalan kebenaran. Yesus berkata dalam injil Yoh 14:6 bahwa: "Akulah jalan dan kebenaran dan hidup. Tidak seorang pun yang dating kepada Bapa kalau tidak melalui Aku." Ayat ini berarti bahwa di luar Yesus tidak ada lagi jalan kebenaran dan hidup. Jadi jika ada yang mengatakan bahwa di sana ada keselamatan dan sebagainya, sebenarnya itu adalah kebohongan.

\section{Membangun Iman Orang Percaya}

Iman adalah dasar dari segala sesuatu yang manusia harapkan. Bahkan iman itu adalah Firman Allah. Manusia diperanakkan oleh Firman itu. Firman itu ada di dalam diri manusia sendiri. Kehidupan Yesus ada di dalam diri manusia dan Allah ingin agar manusia itu percaya kepada Dia.

Sama seperti seorang anak yang harus menerima ajaran rohani, moral dan kecerdasan untuk bertumbuh menjadi manusia dewasa yang bertanggungjawab. Demikian pula seorang Kristen yang sudah lahir baru harus dibimbing untuk bertumbuh dewasa dalam iman. Orang beriman yang lahir baru ini harus bertumbuh dalam persamaan dengan Kristus, dan pribadi yang bertugas untuk mengajar orang percaya adalah Roh Kudus seperti yang tertulis dalam Yohhanes 14: 26 yang mengatakan: "Dialah yang akan mengajarkan segala sesuatu kepadamu". 
Ajaran-ajaran Roh Kudus selalu memimpin orang-orang beriman ke arah pelajaran yang harus dikuasai. Ia memimpin orangorang beriman untuk mengikuti Yesus. Ia memimpin mereka agar menjadi anak-Nya yang selalu menaruh harapan sepenuhnya kepada Yesus. Melalui iman manusia akan dapat mencapai tingkat yang lebih tinggi daripada kemampuannya sendiri, dan hal-hal yang mungkin bagi Allah akan menjadi mungkin bagi manusia. ${ }^{38}$

Iman menghubungkan orang percaya dengan realitas atau kenyataan yang tidak terlihat oleh mata manusia, yaitu Allah. Apabila orang percaya memelihara terus hubungan dengan Allah dengan menaruh iman, orang percaya akan dapat bertahan dan mengatasi segala macam ujian dan penderitaan yang harus dihadapi setiap hari. Selanjutnya, ujian-ujian dan penderitaan itu akan menjadi kesempatan bagi Allah untuk menyatakan kemuahan dan kemuliaan-Nya.

Semua orang yang mau beriman seharusnya terlebih dahulu percaya bahwa Roh Kudus memimpinnya supaya apa yang diimani akan menjadi kenyataan dan bukan menjadi kesia-siaan. Kitab Kisah Para Rasul di mana orang non Yahudi yang baru percaya juga menerima pencurahan Roh Kudus.

Roh Kudus yang tercurah kepada 120 orang pada hari Pentakosta dan seterusnya kepada semua yang percaya tidak hanya dikuasai, dihinggap dan dipenuhi oleh Roh Kudus, tetapi diperlengkapi dengan kuasa untuk melakuan banyak mujizat dan menjadi saksi kepada semua orang (Kis 1:8). Markus mengatakan bahwa mereka akan disertai dengan tanda-tanda yang supranatural dan dahsyat (Mrk 17: 18) karena Roh Kudus ada di dalam mereka.

Ketika bertemu dengan Roh Kudus dan dibaptis di dalam Dia, maka segala sesuatu akan berubah di dalam hidup ini sehingga ada kehausan akan Tuhan Yesus untuk mengenai-Nya lebih dalam lagi. Sifat dan sikap yang lama akan dijadikan-Nya menjadi sama seperti Yesus dan akan menjadi baru.

Saat Roh Kudus dating ke dalam manusia, manusia itu akan mengalami perubahan yang drastic. Mungkin selama ini ia tidak dapat bersaksi, minder, malu dan sebagainya terhadap yang lain. Namun

${ }^{38}$ Alyson Flensa, Perubahan di dalam Dia (Bandung: Andi, 1996), 31. 
ketika Roh Kudus ada dalam dirinya, maka ia akan menjadi orang yang luar biasa yang dipakai oleh Tuhan untuk menjadi alat-Nya.

\section{Memeteraikan Orang Percaya Menjadi Anak-Anak Tuhan}

Gagasan bahwa orang-orang percaya yang penuh dengan Roh Kudus adalah anak-anak Allah, membuat Paulus menggunakan kiasan tentang pengangkatan sebagai anak dalam hubungan dengan pekerjaan Roh. Dalam Roma 8:14-17 mengatakan bahwa "semua orang yang dipimpin Roh allah adalah anak-anak Allah ... "Oleh Roh itu kita bersaru : "ya Abba, ya Bapa!"'. Pada saat itu "Roh bersaksi bersamasama dengan roh kita, bahwa kita adalah anak-anak Allah. Di sini secara khas dikatakan bahwa kesadaran orang pecaya sebagai anak dibangkitkan langsung oleh Roh Kudus. Dengan kata lain, tak seorang pun yang berani menghampiri Allah sebagai Bapa dengan cara yang akrab, sebagaimana ditandai oleh istilah "abba", kecuali dipimpin oleh Roh Kudus.

Dalam Roma 8: 20 lanjutan ayat seterusnya menunjukkan bahwa mereka yang sudah menerima karunia sulung Roh "menantikan pengangkatan sebagai anak, yaitu pembebasantubuh kita".

Dalam Galatia 4:6 Paulus berkata bahwa: "Allah telah menyuruh Roh Anak-Nya masuk dalam hati kita, yang berseru "ya Abba, ya Bapa". Roh yang memampukan Yesus untuk menyarukan "Abba" pada saat penderitaannya ialah Roh yang sama dengan yang sekarang memampukan semua anak-anak Allah yang diangkat-Nya untuk menghampiri Bapa dengan cara yang sama. Ini takkan bisa terjadi tanpa pertolongan Roh kudus di dalam di manusia.

\section{Membuahi Orang Percaya}

Alkitab dengan tegas menyingkapkan sebuah fakta yang merupakan yang merupakan sebuah kebenaran yang di dalamnya memberitauhkan bahwa Roh Kudus membuahi orang percaya. Kalua 
kita membaca Galatia 5; 22-25 maka akan jelas bahwa formulasi hidup orang percaya tepat seperti apa yang dikatakan nats tersebut. ${ }^{39}$

Kalaulah seseorang telah dibuahi oleh tentunya ada karakterristik yang dimilikinya dan karakterristik tersebut adalah memiliki sifat seperti Kristus, keterlibatan dengan penginjilan, dan sikap memuji, dan menyembah mengucapm syukur dan ketundukan kepada Roh Allah. ${ }^{40}$

Pertanyaan yang sering muncul di benak orang adalah bagaimana saya dapat dipenuhi oleh Roh Kudus? Jika kepenuhan dihubungkan dengan penguasaan Roh Kudus yang sudah pasti dibuahi pula oleh Roh yang sama, maka hal tersebut dapat dihubungkan dengan penyerahan diri secara totol, maksudnya orang percaya bersedia mengijinkan Roh Kudus melakukan apa saja yang Dia kehendaki, maka hasilnya adalah hidup yang memiliki karakter seperti Kristus. ${ }^{41}$

Contoh-contoh hidup orang percaya yang menghasilkan buah dapat di klasifikasikan seperti berikut ini: menuruti firman, taat, rajin berdoa, memberitakan injil, berpuasa, rajin membaca alkitab, suka mendengarkan firman Tuhan, melakukan firman Tuhan, bersaksi kepada orang yang belum mengenal Tuhan, menjadi contoh kepada semua orang.

Orang yang sudah dipenuhi dengan Roh Kudus akan dapat menghasilkan kerakter Allah di dalam dirinya secara pribadi. Cara hidup lama dapat dimatikan karena cara hidup baru di dalam Kristus ada pada manusia saat Roh Kudus turun ke atasnya.

Memang merupakan hal yang sulit untuk mengubah cara hidup yang lama karena untuk mengubahnya itu membutuhkan waktu yang lama bagi seseorang untuk berubah. Manusia tidak dapat berubah secara drastis karena untuk hidup dalam kekudusan dan kebenaran, maka dibutuhkan pertobatan yang dari hati yang dalam dan bukannya dari pemikiran atau ikut-ikutan.

\section{Penerapan Dalam Kelas Pendidikan Agama Kristen}

\footnotetext{
${ }^{39}$ Flensa, Perubahan di dalam Dia, 32.

${ }^{40}$ Ibid, 32.

${ }^{41}$ Ibid, 34.
} 
Pelaksanaan kelas pendidikan agama Kristen dapat dijumpai dimana saja, baik di rumah, sekolah maupun gereja, untuk itu pelaksanaan kelas-kelas dalam pendidikan agama Kristen haruslah dilaksanakan dengan konsep dan metode yang benar sehingga kelas pendidikan agama Kristen itu dapat berjalan dengan baik, tak terkecuali menghadirkan Roh Kudus dalam kelas itu sendiri. Harro Van Bomel dalam bukunya "Berjalan Bersama Tuhan Di dalam Kelas" menjelaskan bahwa kehadiran Roh Kudus dalam memimbing kita sangat terasa, sehingga dalam setiap proses elajar mengajar, setiap anggota kelas yang merupakan orang percaya dapat dengan segera merasakan manfaat dari hadirnya Allah dalam kelas tersebut. ${ }^{42}$

Setiap murid yang belajar akan senantiasa menunjukkan sikap yang dipenuhi Roh, sehingga tak heran murid yang telah dipenuhi Roh menunjukkan sikap dewasa dalam rohaninya, oleh seba itu adalah menjadi keharusan yang mutlak apabila pekerjaan dan karya-karya Roh Kudus itu benar-benar dapat diterapkan dalam setiap kelas di pendidikan agama Kristen.

\section{Kesimpulan}

Orang percaya adalah orang-orang yang yang telah ditebus oleh Kristus dengan darah-Nya, dan orang percaya yang telah ditebus ini, adalah orang-orang yang telah dilahirkan kembali oleh Roh sehingga orang percaya menjadi orang-orang yang didiami Roh Kudus sebagai Bait-Nya. Dengan tinggalnya Roh Kudus dalam hati orang percaya maka Roh Kudus akan berkarya untuk senantiasa membuat orang percaya melakukan semua yang baik dan benar, karena itulah yang diinginkan Allah dalam hidup ini.

Peranan Roh Kudus dalam hidup orang percaya itu sangat banyak, dan hendaknya setiap orang percaya benar-benar menjadi umat yang senantiasa diurapi dan dipenuhi oleh Roh agar pertumbuhan iman orang percaya dapat berjalan terus, untuk itu dalam setiap pembelajaran orang percaya kepada Tuhan, Roh Kudus akan senantiasa menuntun, membiming dan mengarahkan orang percaya sehingga mereka dapat menjadi orang percaya yang beriman tangguh.

\footnotetext{
${ }^{42}$ Flensa, Perubahan di dalam Dia, 35.
} 
Penerapan dari peranan Roh Kudus dalam hidup orang percaya ini dapat diterapkan dikelas-kelas pendidikan agama Kristen, baik itu dirumah, sekolah maupun gereja, dan hendaknya proses belajar mengajar yang melibatkan Roh Kudus akan berdampak positif bagi setiap pembelajar yang ikut belajar di dalamnya. 


\section{DAFTAR PUSTAKA}

Bennet, Ritta. The Holy Spirit and You. Zondervan, t.t.

Enns, Paul. The Moody Handbook of Theology. Malang: Literatur SAAT, 2003.

Feinberg, C. L. Ensiklopedi Alkitab Masa Kini Jilid II, diterjemahkan oleh M. H. Simanungkalit, disunting oleh H. A. Oppusunggu. Jakarta: Yayasan Komunikasi Bina Kasih/OMF, 1992.

Fermer, M. T. Ensiklopedi Alkitab Masa Kini Jilid II, diterjemahkan oleh J. M. Pattiasina, disunting oleh H.A. Oppusunggu. Jakarta: Yayasan Komunikasi Bina Kasih/OMF, 1992.

Flensa, Alyson. Perubahan di dalam Dia. Bandung: Andi, 1996.

Hadiwijono, H. Iman Kristen. Jakarta: Bpk Gunung Mulia, 1982.

Hinn, Benny. Selamat Datang Roh Kudus. Jakarta: Imanuel Publishing House, 2004.

Moris, L. L. Ensiklopedi Alkitab Masa Kini, pen. M. H. Simanungkalit. Jakarta: Yayasan Komunikasi Bina Kasih/OMF, 1992.

Poerdarminta, W.J.S, Kamus Umum Bahasa Indonesia. Jakarta: PN Balai Pustaka, 1984.

Prince, Derek. Iman yang olehnya kita hidup. Jakarta: Yayasan perkabaran injil "Imanuel",1993.

Sappington, Tom. Diktat Pneumatologi.. STII Yogyakarta: 1998.

Saucy, Robert L. The Church in God's Program. Chicago: Moody, 1972.

Tim Penyusun Kamus Pusat Bahasa, Kamus Bahasa Indonesia vol. 3. Jakarta: Balai Pustaka, 2002.

Tong, Stephen. From Faith to Faith. Surabaya: Momentum, 2001.

Wiglesworth, Smith. Urapan Roh-Nya. Bandung: Rivival Publishing House, 2000.

Wigleswoth, Smith. Jamahan Roh Kudus. Bandung: Revival Publishing house, 2002. 